\title{
An empirical study of Women Entrepreneurship motivational factors in Botswana
}

\author{
Khulekani Sibanda \\ University of South Africa, Botswana \\ Email: sibandak32@gmail.com
}

\begin{abstract}
Women entrepreneurship plays a significant role in the economic development of a nation's economy; thus, this study was set up to study the main motivations of women entrepreneurs in Botswana. The findings revealed that the women entrepreneurs in Botswana are motivated by a range of issues to start business both the pull and push factors. It was thus recommended that the government should provide sufficient infrastructural facilities along with the routine concessions and incentives to women entrepreneurs in the region. For better results, there should be co-ordination among the various agencies involved, without any overlapping of the functions. Flexibility and timely assistance by the financial institutions would help the women entrepreneurs to survive profitably, despite the entry of multinationals into the country and region. The officials of both the government and the banks should take initiative in the matter of financial and promotional assistance to the new and prospective women entrepreneurs.
\end{abstract}

Keywords Entrepreneurship, women's entrepreneurship, formal business, informal business, Microenterprise, Small business, business growth, Economic development, Diversification

\section{Introduction}

The contribution of women to the process of development is widely accepted. Women at present have broken the monopoly of men and proved themselves that they are not inferior to men. Today, the role of women is not confined to the traditional one as a mother/housewife. The role of modem women is much more than what it was previously. Recently, entrepreneurship among women has become an important topic of concern in Botswana. Women constitute almost half of the total population in the country. They play a positive and constructive role in the socio-economic development of the country. In case of rural areas, there is a significant change in the women's role. The women have openly come out from their traditional roles. The women entrepreneurs can stand on their own foot by acquiring a necessary skill through education and training. A variety of programmes have been undertaken in Botswana in recent years to develop entrepreneurship among women. The Government has initiated a number of measures for women entrepreneurship development by way of granting a variety of special concessions, incentives, subsidies, rebates and assistance. Several women's organisations at national and regional, levels have sponsored a number of conferences and workshop in recent times. It gave a great moral support and inspiration for the women entrepreneurs. Better supply of entrepreneurs in any country can be an asset and inspiration for adequate development of economy. Entrepreneurs are the heroes and heroines in the drama of economic development of the country. They move heaven and earth in the theatre of the nation's economy to accelerate the process of economic development through innovations, moderate risk-bearing, adventurism and optimum co-ordination of factors of production. Entrepreneurship development, especially women entrepreneurship is the insistent need of the hour. Botswana needs dynamic and energetic entrepreneurs who will innovate 
organisation, technology and products, thus this study seeks to look at the motivational factors that inspire women in Botswana to consider entrepreneurship as a profession.

A brief and selective review of literature on entrepreneurship in general and women entrepreneurship will not be out of place here. Many scholars have shown great interest in studying the various aspects of entrepreneurship in Botswana but research work on women entrepreneurship is still very limited and only a handful research works have been. The research on women entrepreneurs at the national level is encouraged by institutions and agencies working in the field. There are a good number of researchers that have been undertaken by many scholars in the field of entrepreneurship. However, a study of women entrepreneur's motivational factors at a national level is yet to gain that importance, these micro-level studies are of immense use to know various aspects of the problems. Similarly, such studies will be of some use to financial and development institutions to plan their programmes considering specific requirements of entrepreneurs in the region. In the economically and industrially developing regions of Botswana, the importance of such research cannot be ignored.

The absence of research to perceive and address the concerns experienced by these women who occupy an essential part of the Botswana economy has rendered them worthless and their potential under-used. According to Ama et al. (2014), facing different hindrances in business creation and undertaking impacts women' profit and has adverse money related, societal, and partisan outcomes for nations. Absence of information on obstructions to women' section or accomplishment in business makes the system definition badly designed and impacts their business achievement.; the third explanation behind this evaluation is to examine and see the issues Batswana female business people take a gander at around the start-up and progress times of their affiliations. This will consolidate getting some answers concerning the issues and difficulties female businesspeople face from creating an economic perspective to adversity to develop their affiliations. Such information will, in like way, be important to government policymakers in making sense of how to help these women, making the subject of their affiliations' accomplishment of generally progressively basic vitality.

\section{Literature Review}

Female entrepreneurs are propelled by different components to begin businesses (Hassan, 2016), (Sudarmanti et al., 2013) and (Rossi et al., 2013). What is fundamental in moving women to start businesses is essentially the necessity for mindfulness, welfare thoughts, selffulfilment considerations, the prerequisite for budgetary self-sufficiency, and the precondition for affirmation. In any case, a thorough portrayal of female representatives is given by the Global Entrepreneurship Monitor in the wake of thinking about countries around the globe (GEM, 2016/2017). They theorize two essential theories of business motivations. These are composed of opportunity and necessity business visionaries.

\subsection{Opportunity Entrepreneurship}

Concerning works by Petrakis and Kostis (2014), Opportunity Entrepreneurs are depicted as the people who respond to 'pull' factors that attract them to start a business. These pull factors can exist in the market. Opportunity Entrepreneurs see some eccentric potential opportunities, which they cannot remain to miss and take up these innovations. Opportunity is the limit that is competency-based rather than inadequacy based. Women' ability should recognize an opportunity and a brief period later having the benefits of taking advantage of that opportunity. Presently researchers may find that there exists a causal connection that they can 
take advantage of to start another business.

Another force factor would be for the women to verify opportunity from a male position, as found in standard male-driven social solicitations whereby women are required to stick to their gender-based activities which include cooking for the family, sewing and taking care of the children notwithstanding giving marital rights to their spouses (Hassan, 2016). Owning a business would mean the dispatch of subservience to their spouses and changing to be their bosses in the world of business. Such Women can, here and there, get psychological satisfaction as they are female pioneers, and they pursue after their own needs that will satisfy them as individuals. Another related motivational factor driving these women to consider entrepreneurship as a profession is the desire to succeed and get a challenging occupation (Rossi et al., 2013). A few women may likewise start a business if they have the required capital and would be willing to take advantage of the available opportunity identified within the market.

\subsection{Pull and Push Factors}

Some ongoing specialists demonstrate that few women are turning out to be businesspeople particularly working-class women because of the pull and push of customary and evolving values (Kirkwood, 2009). Under the pull factors, women businesspeople pick a calling as a test, as experience with an inclination to explore new territory and to have an autonomous occupation. Under the push factors, women take up business undertakings to get over money related challenges when duty is pushed on them because of family conditions. Women businesspeople wandered into their business in light of certain impulses. The impulses referred to be the demise of a spouse who was on business, joblessness, to enhance small pay at home, to receive a superior way of life, and to settle youngsters. The gathering particularly falls under the push class of business visionaries who depended on the pioneering calling as a result of certain impulses.

Pull factors allude to circumstances or openings being too alluring to ever be overlooked by the perceiver, while the push factors signify a reaction conceived out of superfluous impulses (Kirkwood, 2009). While perfect, unalloyed instances of pull or push factors are difficult to find, in actuality, circumstances there is quite often a blend of the two-the differentiation may, by the by, be helpful as a casing of reference, For they mean, generally, positive and negative reactions to explicit circumstances. All things considered, both in the provincial and urban areas women particularly having a place with the working class are prepared towards enterprise to satisfy their desires both monetarily and socially. In Botswana women, an enterprise can be considered as a need business enterprise as opposed to circumstance business enterprise. Women, as a rule, have littler systems and less topographical versatility than men, all the more so on account of youthful, wedded women who need to deal with their families. These women can utilize their abilities and accessible neighborhood assets to begin their undertakings. In any case, the area of the venture and the quality of associations with contacts are significant as it determines the business visionary's capacity to get and utilize the assets accessible in her locale.

\subsection{Necessity Entrepreneurship}

The GEM (2016/2017) defines the second type of female entrepreneurship as necessity entrepreneurship. It perceives necessity entrepreneurs the same as the entrepreneurs who start a business due to 'push factors.' They are moved to begin a new business venture because of different conditions that drive them to enter a specific kind of business. Necessity 
entrepreneurship is condition driven. Push elements might be joblessness or low paying job and the need for survival. Giacomin et al. (2011) concluded that some women may start new businesses because of the need to support their children as single parents as a result of high separation and divorce rates among families. Such entrepreneurs routinely start a business without satisfactory assets or enter those industries, which are peripheries and unfruitful. They often have no choice since not doing the business would spell critical outcomes for them. Organizations like these are probably not going to contribute much to the economy as they may have negligible benefits and would likely be controlled by proprietors themselves.

\subsection{Variants in the Quest of Entrepreneurism}

A couple of researchers acknowledge that there are variations of how one approaches the procedure of entrepreneurship. The social settings build up how one would access and look for after business ownership. Those social builds incorporate where and how the start-up capital is gathered, the kind of relational associations that are utilized, the availability of opportunities, and innovative improvement (Weller, 2010). Wong (2009) inferred that entrepreneurship and social stratification should be observed at the same time. They portray social stratification "as the last result of institutional methods that divide society into advantaged and disadvantaged socially created groups." There are advantaged and oppressed groups, and after some time, the announcement of vitality and resources by the uncommon group is sustained. At the end of the day, the individuals from the advantaged groups within the society would approach the procedure of business enterprise uniquely in contrast to an individual from a distraught group.

\subsection{Social Influences}

Societal standards direct the reason and way that one takes to end up a business visionary. Women have dependably had an obligation regarding others, regardless of whether they were posterity or other relatives. Accordingly, they entered the workforce with the truth that they needed to gain cash for survival purposes (Kyaruzi and Mar 2015). Albeit Women originate from different financial foundations, they share social standards in light of their one of a kind social history, which may affect their inspiration and choice to end up businesspeople (Alam, et al., 2011, Aswaddalai, 2015)

Women originate from various social foundations that lead them into entrepreneurism. Because of the low salary of the male partner or his nonattendance in the home, a few Women have the sole duty of creating monetary assets for their families. With an end goal to accommodate their families, they combine their imagination and aptitudes to create a business that will even provide employment not only for themselves but for their families as well. Then again, other female entrepreneurs originate from families whose guardians were entrepreneurs, or maybe we're doing great in their situations in top-level administration, however, they felt that they were not going to accomplish any higher than their present position. The passionate pain of breaking the "glass ceiling" (Wang, 2016), alongside the mental sadness expedited by years of moving, has propelled Women to look for choices for an enhanced mental state while creating enormous income (Fay-Spina, 2017) Also, job discrimination in earlier years has brought about women, in general, coming into the workforce through enterprise or organizations claimed by women. 


\subsection{Psychological Influences}

In connection with the shifting that is being done by women in the working environment, says that shifting also proceeds at home when managing the requirements of her male partner. Even though she may have had a testing day at the workplace, there are times when she will stay quiet about her day to be a good audience to her loved one. If she is a single parent, she additionally takes after a similar practice with her youngsters keeping in mind the end goal to give them the consideration they require. Not exclusively does this abandon her in a lopsided mental state, she has no opportunity to get emotional support from her family, which prompts disappointment and occasionally sorrow. The quest for entrepreneurism not just gives emotional discharge, it fills in as a feeling of achievement and control conceivably unattained in the work environment, alongside true serenity. What is more, it fills in as an outlet for her to outline new adventures and completely practice self-assurance (Bailey, 2015, Dahlquist, 2014)

\subsection{Social and Emotional Influences}

To balance the quietness followed by shifting, Batswana female business visionaries look for help from each other. The inner encouraging groups of people that are used enable them to support their organizations. These Women entrepreneurs advance each other's organizations and straightforwardly share individual encounters and proposals among themselves with an end goal to add to every women's achievement and, thus, enhance theirs. Their interior systems incorporate companions, family, associates, and places of worship, sororities, and local gatherings. In any case, they don't use casual systems, for example, national systems administration associations, or socially assorted encouraging groups of people, at an indistinguishable rate from casual systems (Ntseane, 2000).

\subsection{Community Involvement}

One of the key identifiers of accomplishment among female entrepreneurs is their commitment to their communities. Numerous women view their work as a calling (Ngare, 2015). The greater part of their community benefit is conscientiously based, social administration, instruction, physical and emotional well-being, and financial advancement. The associations and advisory groups in which these female business visionaries volunteer their services as a rule relating to their expert ability. To outline, a businessperson who owns a fitness centre/ gym will work with a group relating to wellbeing and health. A business visionary whose business helps to mentor youths may volunteer with a coaching program. As such, their decision of group work, for the most part, interfaces straightforwardly to their callings, which creates proportional assets from their organizations to their groups.

While budgetary and economic development is a key factor in the quest for enterprise for these Women, it is not their sole reason motivating them to be entrepreneurs. It is additionally not all that matters when characterizing the achievement of their organizations, nor the base of their inspiration to continue. Their way to deal with getting to be fruitful businesspeople is allencompassing, in that it not just serves their money-related necessities, it enables them to add to their groups on a municipal and social level. They add to the income of their groups by employing its occupants and addressing the necessities of a market. They likewise fill in as good role-models to the individuals who look to emulate their example (Shediak, 2014). Money related achievement is an external motivator. Others can see the results of their work. Nonetheless, female entrepreneurs may use inherent pointers to decide achievement, as they likely fill in as essential motivators for them to continue and accomplish proficient 
development.

\section{Research Methodology}

\subsection{Research Paradigm}

An essential appraisal of the significant physiognomies on this thesis displays that this study falls inside the context of the colouration and descriptive investigation structures that are aligned to the positivist philosophical framework. This evaluation to a degree attempts to cling towards positivism by gathering quantitative information by surveys and by isolating information utilizing quantifiable frameworks (Creswell, 2014).

The exploratory thought of this evaluation suite the phenomenological structure. It portrays and develops an impression of women's business in Botswana by highlighting the difficulties experienced by the women business visionaries and their circumstance as they go about their normal businesses. Qualitative information was gathered through interviews to increase additional data on Batswana women' businesspeople to build an all-around knowledge on their acumen as for the assessment questions. Another basic standard related to the phenomenological perspective as showed by Roman, et al. (2016) which is reflected in this thesis, is how important the approach of interpretive research in increasing necessary knowledge into social issues in its genuine setting. Subsequently, a business undertaking can act as a promoter of community advancement, the steady perspective associated with the evaluation to get and discover acumen of Batswana women Entrepreneurs in their confirmable setting. Right now, interpretive research changed following the phenomenological analyses the perspective included the opinion of the women's businesspeople inside the difficulties of the dynamic Batswana business and social setting (Jeong and Othman, 2016).

\subsection{Research Philosophy}

Research philosophy is a researcher's conviction concerning what establishes the truth of a study being researched on and how information about that study ought to be generated. It directs a strategy that can be utilized to gather, dissect, and apply information to respond to the study question as far as the phenomenon is contemplated (Saunders, et al., 2009). The researcher picks the philosophy that characterizes the individual perceptions of the world. The suspicions understood in this view Impact the procedure utilized to direct study (Saunders et al., 2009:107). Research philosophy can thus be defined as a perspective or hypothesis shared between researchers in a specific discipline concerning how marvels may be comprehended and communicated (Patel, 2015). Three significant philosophical models are identified in writing, which is: constructivism (interpretivism), pragmatism, and positivism. This study used pragmatism philosophical paradigm. The following research onion represents the different research approaches that can be used in a study

\subsection{Research Approaches}

There are mostly two primary sorts of research methodologies, to be specific quantitative and qualitative research methods. The two strategies have their own merits and demerits as they have interchange among expansiveness and profundity, and among the speculation and focusing on a populace. Formulated out of these two research methodologies is the mixed research methodology, which consolidates both the quantitative and the qualitative techniques in a single report. The following is a concise discussion of these three techniques and demonstrating how and when they are applied in research, with the point of in the long run 
picking one methodology to be followed for this Study.

\subsection{The research design}

The research design is depicted as the approach for carrying the research. It demonstrates the general arrangement of how the examination is set up (McMillan and Schumacher, 2010). The motivation behind a research design is to determine the strategy to produce the experimental study that is utilized to respond to the research question, to give believable outcomes. Credibility implies the findings show the truth is exact, dependable, and sensible. Great research designs are portrayed by the accessibility of resources, opportunity from inclination, and the control of unimportant factors (Wiersma and Jurs, 2009). This research will follow three different research designs concerning the study objectives and research questions. It will develop a correlative design, a descriptive design, and lastly, an exploratory design.

\subsection{Population}

The number of inhabitants in an examination study is characterized as the assortment of individuals or enterprises that the researcher plans to make a few deductions, arrive at resolutions, and make suggestions on. Creswell (2014:204), characterizes a research population as all patrons which a scientist wants to investigate, in this case, it relates to all types of formal/casual organizations claimed by women beginning from one individual association (for example tuck-shops and vegetable suppliers), through to huge firms (for instance multinational firms) in the section below, Regarding the associations supported by Gender Affairs Department a sum of 552 associations was focused on.

\subsection{The sample}

A sample is a subset of a population. Sampling can be described as a part of the general population that one desires to study (Natalie , 2018). The main reason for the examination of a sample in preference to the complete population is because the research of the whole population might be prohibitive in terms of cost. It could be most fitting to devote time and different advantages for subsets of the population inside the expectation that any such consciousness of exertion could create a correct element of the phenomenon.

\subsection{Sample Size Determination}

Bush (2015) portrays a sample as a subset of the target individuals from which data is gathered to survey something about the populace. The sample size was drawn using the embraced model by Krejcie, and Morgan (1970) referred to by Kotrik and Higgins (2001), it was utilized to choose the sample size.

$$
s=\frac{X^{2} N P(1-P)}{d^{2}(N-1)+X^{\wedge} 2 p(1-P)}
$$

From this equation, Krejcie and Morgan thought of various sample sizes. For this research, the populace understudy was 552, and the sample size 265.

\subsection{Validity}

Validity is concerned with whether the discoveries are really what they seem to be (Drost, 2011). It is the degree to which data-gathering techniques or strategies accurately measure the purpose they were supposed to gauge. Baxter and Jack (2008) state that no single source has an entire preferred standpoint over all others. The distinctive sources are very reciprocal, and 
a decent contextual analysis should use many sources as could be expected under the circumstances. In this way, validity is concerned about the adequacy of the assessing instrument to test what is to be tried. In such a manner, questionnaire surveys will be pilot tried to guarantee they confront the test, that is, estimating or gathering information that should be collected.

\subsection{Reliability}

While attempting to improve trustworthiness, the researcher grasped a proper testing methodology that ensured the availability of many respondents recognized from the list of all associations enrolled with the Ministry of Gender Affairs. The researcher did not pressurize the respondents; accordingly, he let them respond to their evaluation without inclination or pressure from the researcher. In a way to improve Reliability, the researcher used triangulation or similar structures constancy, which incorporates utilizing two research instruments on comparative wonders and research results to check on the off chance that they produce identical outcomes. Finally, to decide reliability, the researcher did a pilot study with five women business people who are his partners to test if the survey was fit for a reason and in case it ought to be calibrated, and it worked commendably.

\section{Findings and Discussions}

\subsection{Main motivations of women to consider entrepreneurship}

The most critical inspirations for women to consider enterprise are the requirement for freedom, absence of business openings, the need for an adaptable calendar, and finally inadequate salary dependent on the mean qualities that appeared in Table 1.11. Considering that single women control most SMEs in the examination, it is not astounding that there is a substantial requirement for autonomy. The findings agree with the views of (Bui, et al., 2018) and (Hassan, 2016) who announced that women view beginning business opportunities as an opportunity to break-away from male control, this has been the trend in most man-centric social orders in the developing countries. The discoveries indicate the opportunity-driven way to deal with enterprise rather than the need-based way to deal with business. McGowan, et al. (2012) concur that the more prominent requirement for freedom among women businesspeople was a motivator driving women to start their businesses. They acknowledged that when contrasted with men, self-governance is even more communicated as an incredible inspiration to begin a business.

Similarly, the quest for freedom has been seen to be a motivator for both rural and urban women among Indians (Jyoti, Jyoti, and Anita: 2015). It could be concluded that the more significant part of women is aligned to the opportunity factors rather than push elements which are found with low mean values as compared to the requirement for employment opportunities. Hypothetically, it tends to be viewed as simple to arrange women motivational factors for entrepreneurship based on Schaffe and Gaffe (985) typologies. In the present investigation, the typologies appear to traverse different classes suggesting that inspirations for entrepreneurship may not be viewed as a one-dimensional build.

Also, they identify with this kind of enterprise in the exhibition of resource-rich nations. Ongoing insights demonstrate that Botswana is the subsequent one of the best-performing economies in Southern Africa, dependent on its GDP, giving more prominent chances to business than different countries in a similar region (SADC: 2018). Even though reviews have been done on the connection between GDP and innovative inspiration, the researcher finds the 
arrangement of thought processes on the need-based, opportunity-based and individual desire based to be distorted as most researchers would need us to believe, but instead a blend of any of the majority of the classifications.

Table 1. Main motivations for entrepreneurship

\begin{tabular}{|l|r|r|r|}
\hline Motivation & Mean & Std. Deviation & \multicolumn{1}{|l|}{ Skewness } \\
\hline The need for independence & 4.1765 & 0.87528 & -1.228 \\
\hline Lack of employment opportunities & 4.0353 & 1.18971 & -1.286 \\
\hline The need for a flexible schedule & $\mathbf{3 . 9 7 6 5}$ & $\mathbf{0 . 8 5 8 8}$ & $\mathbf{- 0 . 7 6 3}$ \\
\hline Insufficient income & 3.9412 & 1.05054 & -0.89 \\
\hline Self-fulfilment & 3.8588 & 1.07075 & -0.725 \\
\hline $\begin{array}{l}\text { Role model and other people } \\
\text { influences }\end{array}$ & 3.8118 & 1.07453 & -0.734 \\
\hline The need for a challenge & 3.7412 & 0.97776 & -0.55 \\
\hline Ensure high job security & 3.5882 & 1.27517 & -0.484 \\
\hline The need to develop a hobby & 3.5765 & 0.98048 & -0.297 \\
\hline Entered the family business & 3.2353 & 1.2597 & -0.276 \\
\hline Lost jobs & 3.2118 & 1.33714 & -0.338 \\
\hline Confidence in service or product & 2.9529 & 2.05812 & -0.565 \\
\hline
\end{tabular}

Table 1. Variables: Motivations for Business Ownership

\begin{tabular}{|l|l|l|l|l|l|}
\hline MOTIVATION FACTORS & $\begin{array}{l}\text { Strongly } \\
\text { disagree }\end{array}$ & Disagree & Neutral & Agree & $\begin{array}{l}\text { Strongly } \\
\text { Agree }\end{array}$ \\
\hline The need for independence & $1.2 \%$ & $4.7 \%$ & $9.4 \%$ & $44.7 \%$ & $40 \%$ \\
\hline $\begin{array}{l}\text { The need for a flexible } \\
\text { schedule }\end{array}$ & $1.2 \%$ & $3.5 \%$ & $20 \%$ & $47.1 \%$ & $28.2 \%$ \\
\hline The need for a challenge & $2.4 \%$ & $7.1 \%$ & $28.2 \%$ & $38.8 \%$ & $23.5 \%$ \\
\hline Self-fulfilment & $2.4 \%$ & $10.6 \%$ & $18.8 \%$ & $35.3 \%$ & $32.9 \%$ \\
\hline Slow career progression & $1.2 \%$ & $14.1 \%$ & $28.2 \%$ & $38.8 \%$ & $17.6 \%$ \\
\hline $\begin{array}{l}\text { Role model and other people } \\
\text { influences }\end{array}$ & $2.4 \%$ & $12.9 \%$ & $15.3 \%$ & $40 \%$ & $29 \%$ \\
\hline Redundancy (Lost jobs) & $15.3 \%$ & $16.5 \%$ & $17.6 \%$ & $32.9 \%$ & $17.6 \%$ \\
\hline $\begin{array}{l}\text { Lack of } \\
\text { opportunities }\end{array}$ & $7.1 \%$ & $4.7 \%$ & $11.8 \%$ & $30.6 \%$ & $45.9 \%$ \\
\hline Insufficient income & $3.5 \%$ & $4.7 \%$ & $22.4 \%$ & $32.9 \%$ & $36.5 \%$ \\
\hline Ensure high job security & $7.1 \%$ & $15.3 \%$ & $21.2 \%$ & $24.7 \%$ & $31.8 \%$ \\
\hline Entered the family business & $10.6 \%$ & $21.2 \%$ & $18.8 \%$ & $32.9 \%$ & $16.5 \%$ \\
\hline Confidence in service/ product & $1.2 \%$ & $1.2 \%$ & $11.8 \%$ & $25.9 \%$ & $30.6 \%$ \\
\hline
\end{tabular}




\subsection{Interview motivation themes on flexible work schedules}

The Women clarified in the gatherings that they felt that it was hard to blend family responsibilities, which included dealing with their youngsters and family duties, with work at their past work with its fixed work routines and rules. They further clarified that they didn't get a great deal of help from their spouses in assisting with a portion of these tasks, so it was most phenomenally badly arranged and disturbing for them to join work in their legitimate business and their family commitments. Their endeavour to harden work and family commitments simply acknowledged they were putting less time and obligation in their past employments showed up distinctively concerning their male assistants. Time and duty were the measures considered for movement for the women in their past work.

These Women expected to investigate productive work while playing out their family responsibilities, and undertakings allowed them the chance. One of the women business visionaries talked with who has a bistro remarked:

Kifilwe: -Going into business has managed me the adaptability I have to oversee both my business and family duties at my own pace. I am my special manager now; I am presently ready to deal with my time myself with no fixed calendar, I can close my business at whatever point I need to so I can take care of my family issues. I am an upbeat lady now. (individual correspondence, June 25, 2019

\subsection{Individual motivations for Business Proprietorship}

The individual clarifications behind the women making their endeavours have been inquired. The need to be fulfilled has been perceived and depicted by (Gayatri and Udhayakumar, 2018) as the most captivating of the vast number of motivations for women's entrepreneurs 'business ownership. Seven key individual components were assessed most significantly by the respondents and seen as critical, and the situating was done by getting the consolidated rates among agreeing and strongly Agree from table 5.14. These were: the need for independence $(84.7 \%)$; the need for a flexible work schedule $(75.3 \%)$; Insufficient income (69.4\%); Role model and other people influences (69\%); self-fulfilment (68.2\%); the need for a challenge $(62.3 \%)$; confidence in the service or product $(56.5 \%)$. Another two individual factors in like manner saw as noteworthy was the need to develop a hobby (56.4\%), and to ensure high job security (56.5\%). The least assessed individual factor, which was basic to half $(49.5 \%)$ of the respondents, was looking for after an independent organization.

Along these lines, were strong motivations for business ownership by Batswana women entrepreneurs; this accords with the disclosures of (Poonam and Singh, 2006), in their investigation, they assessed the effect of essential components and occupation strain on female representatives in Jammu, India. The study established that free occupation (82.5 per cent ) situated first among individual rousing segments, Existence of business starting at now in the family ( 97.5 per cent ) situated first among non-individual convincing components sought after by the need to get over the economic-related issue ( 92.08 per cent ). A large portion of the respondents settled their dispute by tackling needs (55 per cent). The accompanying variable by working harder did not point to a sound part to manage pressure (27 per cent). The remainder of the respondents recognized the condition (11 per cent), which was a specific part, and 7 per cent of respondents, depending upon their trust in God. 


\subsection{Interview findings on the main motivations of women entrepreneurs}

Interviews were done with the women entrepreneurs to find out in more detail what motivated them to consider entrepreneurship as a career. One important finding that emerged from the interviews was that the entrepreneur's family members play a vital role in giving shape to an entrepreneur's ambition. In this classification, it was observed that in two cases. When asked about what motivated them to start their businesses, they had this to say.

Gobitsaone: - she said that she wanted to do something to utilize her knowledge for her own sake and never wanted to do routine work. Also, she feels that there is no scope in doing a job. She lamented that her family has been so supportive in helping her achieve her goals

Tshepiso: - she said that she received all the necessary support from her husband and children who played a major role in the establishment of her business. She said when she started she discussed her proposal with her husband who agreed to it and additionally offered a place close to his office to start the business so that he can also look after her work in case of emergency.

Entrepreneurs' fulfilment of the desire of one's own or family members' desire is backed by the experience gained and/or the training received. Most of the sample women entrepreneurs who desired to enter into the business for the fulfilment of their desire received very strong support either from their family members or friends. The above observations are indicative of the fact that various factors enable women to become entrepreneurs. These factors can be classified as "Pull factors" and "Push factors". Pull factors are those when a person chooses a profession as a challenge, adventure with an urge to do something new, liking for business, and have an independent occupation. In a push factor, the business enterprises are taken up either due to financial necessities or due to family responsibilities. The interviews with women revealed that most of the women in the sample study, have willingly become entrepreneurs i.e. they had either individual desire, motivation or had acquired experience in the field. Many at times it is said that it is the compulsion than the ambition that leads a human being to venture into an enterprise.

However, contrary to this belief, it was observed that out of a total sample of 20, 3 women have become entrepreneurs for independent living. Out of these 3 women entrepreneurs, 2 of them were forced to enter into business. One of the women was divorced having two children and she did not have any financial support either from her parents and therefore was forced to start something on her own. Due to the sudden death of their husband, the second woman had no alternative but to think of some source of living of her own. Ambitions/compulsions alone may not make an entrepreneur. The findings reveal that the encouragement an entrepreneur gets from her family members particularly her husband or her friends and relatives, the experience she gains in employment or otherwise, the skills she has acquired or inherited are also the important factors that facilitate entrepreneurship. The findings also revealed that these women entrepreneurs have set moderately difficult but potentially achievable goals for themselves. They prefer to solve a problem rather than to leave the outcome to chance or others. They are concerned with personal achievements rather than with the reward of success. This leads to other characteristics, namely a strong preference for work situations, in which they get concrete feedback on how well they are doing. 


\section{Conclusions}

The fear that developing entrepreneurship among women would break the traditional nucleus social system of society is unfolded and baseless. There is huge but unutilised, untapped potential in this second grade' citizen of our country. What they lack is not innate will and inclination nor motivation but supportive climate where their motivation to be financially independent and to excel is charged their vision for action is sharpened. From this point of view, the motivation of women needs to be encouraged in many ways. The following suggestions are made to improve the motivation of women entrepreneurs in Botswana in particular and other developing regions in general.

The fear element in the woman that as 'she is a woman' hence she is less competent, less capable, less efficient should be removed. The administration should step up and sort out an enormous number of helpful social orders that will be a motivation for women business visionaries to think about the enterprise as a calling. The country requires an enormous number of businesspeople, women support around there is irrelevant. Be that as it may, countless women are having idle level characteristics of business enterprise that ought to be changed over into fruitful business visionaries by the powerful dynamic interest of women in this segment. The administration and NGOs should approach to contribute considerably toward this path. Role models of overcoming adversity of women business visionaries from different foundations ought to be promoted through course books of schools and universities. Every conceivable medium ought to be utilized to extend these good examples, this will have the option to inspire other women who want to begin their organizations. Housewives as a potential wellspring of business enterprise ought to be focused by legislative and different organizations. Endeavors ought to be made to find enterprising possibilities among housewives and openings ought to be given to them.

\section{References}

Chiloane, E. T., 2013. An investigation into the finanacial barriers facing women entrepreneurs operating in SMME's in Tshwane, South Africa. Journal of Economic and Financial Sciences, 6(2), pp. 347-358.

Amita \& Singh, J., 2014. Factors of motivation for women entrepreneurs-a filed study in Haryana. EXCEL International Journal of Multidisciplinary Management Studies, , 4(1), pp. 267-277.

Bailey, C. L., 2015. African American Female Entrepreneurs : What Motivates them to pursue Entrepreneurship, Michigan: UMI ProQuest LLC.

Batsalelwang, K. J., 2015. The informal business sector; a survival strategy for female urban dwellers in Gaborone, Botswana. [Online] Available at: $\quad \underline{\text { http://ubrisa.ub.bw/handle/10311/1370 }}$ [Accessed 228 2019].

Bui, H. T., Kuan, A. \& Chu, T. T., 2018. Female entrepreneurship in patriarchal society: motivation and challenges. Journal of small business and entrepreneurship, , 30(4), pp. 325343.

Creswell, J. W., 2003. Research design: Quantitative, qualitative and mixed methods approaches. 2nd ed. Thousand Oaks: Sage. 
Creswell, W. J., Plano , C., Gutman, L. M. \& Hans, 2007. Advanced mixed methods research designs. Califonia: Thousand Oaks, Sage.

Das, M., 2001. Women Entrepreneurs from India:Problems, Motivations and Success Factors. Journal of small businesses and entrepreneurship, Issue 15 (4), pp. 67-84.

Drost, E. A., 2011. Validity and reliability in social science research. Education research and perspectives, , 38(1), pp. 105-123.

Fairlie, R. W. \& Fossen, F. M., 2018. Opportunity versus Necessity Entrepreneurship: Two Components of Business Creation.

[Online] Available at: https://escholarship.org/uc/item/54h3q4k9

[Accessed 39 2019].

Hanson, S., 2009. Changing Places Through Women's Entrepreneurship. Economic Geography, , 85(3), pp. 245-267.

Hassan, R. A., 2016. Key influencing factors on entrepreneurial motivation among women entrepreneurs. Journal of Research in Business, Economics and Management, , 6(2), pp. 894899.

Hovorka, A. J. \& Dietrich, D., 2011. Entrepreneurship as a Gendered Process. The international journal of entrepreneurship and innovation, , 12(1), pp. 55-65.

Johnson, B. \& Onwuegbuzie, A. J., 2004. A Research Paradigm Whose Time Has Come' Educational Researcher. Mixed Methods Research:, 33(7), pp. 14-16.

Kalyani, B. \& Kumar, D., 2011. Motivational factors, entrepreneurship and education: Study with reference to women in SMEs. The Far East Journal of Psychology and Business, Issue 2, pp. 14-35.

Kebaneilwe, M. D., 2017. 'A Woman of Courage': An Interpretation of the Biblical Hebrew Perspective in Relation to Women and Business in Botswana. [Online] Available at: http://journals.ub.bw/index.php/bnr/article/view/870/523

[Accessed 228 2019].

Kitindi, E. G., 2006. BARRIERS TO GROWTH OF URBAN-BASED SMALL SCALE FEMALE ENTREPRENEURSHIP IN BOTSWANA. [Online] Available at: $\quad \underline{\text { https://journals.co.za/content/biac/3/2/aja17291070_88 }}$ [Accessed 228 2018].

Natalie $\quad$ B., $2018 . \quad$ study.com. [Online] Available at: https://study.com/academy/lesson/what-is-sampling-in-research-definitionmethods-importance.html

[Accessed 10 January 2019].

Ntseane, G. P., 2000. A Botswana Rural Women's Transition to Urban Small Business Success: Collective Struggles, Collective Learning. [Online] Available at: http://newprairiepress.org/cgi/viewcontent.cgi?article=2203\&context=aerc [Accessed 49 2018].

Petitt, A., 2016. Women's cattle ownership in Botswana. [Online] Available at: https://pub.epsilon.slu.se/13205

[Accessed 228 2019]. 
Rametse, N. \& Huq, A., 2014. Factors influencing Attitudes of Women Students to Business Ownership: Lessons and Experiences from the University of Botswana. [Online] Available at: http://researchbank.rmit.edu.au/view/rmit:24588

[Accessed 228 2019].

Rametse, N. \& Huq, A., 2015. Social influences on entrepreneurial aspirations of higher education students: Empirical evidence from the University of Botswana women students. [Online]

Available at:

https://tandfonline.com/doi/full/10.1080/13215906.2015.1018381 [Accessed 228 2019].

Ruane, M. C. M., 2010. Nene and Her Businesses: Entrepreneurship by Necessity. International Journal of Entrepreneurship, , 14(), p. 75.

Smith, D., 2010. The Role of Entrepreneurship in Economic Growth. Undergraduate Economic Review, , 6(1), p. 7.

Statistics Botswana, 2013. Botswana core welfare indicator survey 2009/10, Main Report, Vol. 1, Gaborone: Government Printers.

Werbner, P., 2010. Appropriating Social Citizenship: Women's Labour, Poverty, and Entrepreneurship in the Manual Workers Union of Botswana. Journal of Southern African Studies, , 36(3), pp. 693-710.

\section{Copyrights}

Copyright for this article is retained by the author(s), with first publication rights granted to the journal.

This is an open-access article distributed under the terms and conditions of the Creative Commons Attribution license (http://creativecommons.org/licenses/by/4.0/) 